\title{
VOLUNTARY BREATHHOLDING. II. THE RELATION OF THE MAXIMUM TIME OF BREATHHOLDING TO THE OXYGEN TENSION OF THE INSPIRED AIR ${ }^{1}$
}

\author{
By GEORGE L. ENGEL, EUGENE B. FERRIS, JOSEPH P. WEBB, AND \\ CHARLES D. STEVENS \\ (From the Departments of Internal Medicine and Psychiatry, University of Cincinnati, College

$$
\text { of Medicine) }
$$

(Received for publication April 22, 1946)

The striking effect of 100 per cent oxygen in lengthening the period of voluntary breathholding became apparent to us during experiments concerned with underwater weighing, in which it was desirable for the subjects to remain immersed as long as possible. Although a few observers $(1,2)$ have noted this effect of oxygen previously, it has received very little attention in the literature since World War I; and some, notably Schneider (3), concluded that oxygen had a relatively insignificant influence upon the breathholding time.

The studies reported herewith were originally presented (4) as a method for demonstrating objective physiological effects of relatively small changes in altitude $\left(\mathrm{pO}_{2}\right.$, oxygen tension $)$. This seemed important, because most functional tests of anoxemia do not reveal changes until altitudes of 12,000 to 16,000 feet are reached. These studies show conclusively that a close relation does exist between variations in maximum voluntary breathholding time and those of the $\mathrm{pO}_{2}$ of inspired air. This relationship is of interest, because it offers a simple quantitative functional test which is sensitive to relatively slight changes in $\mathrm{pO}_{2}$ of inspired air, and also because it throws considerable light on the interrelation of oxygen and $\mathrm{CO}_{2}$ as stimulants which force the subject to start breathing after a period of breathholding.

\section{METHODS}

The subjects used in these studies were 40 normal, healthy males, all medical students, with the exception of 4 members of the laboratory team; the mean age of the group was 24 years. The breathholding tests were run on 3 groups of subjects under the following conditions: (1) Ground $(746 \mathrm{~mm} . \mathrm{Hg}), 7,000$ feet $(586 \mathrm{~mm} . \mathrm{Hg})$,

\footnotetext{
1 The work described in this paper was done under a contract, recommended by the Committee on Medical Research, between the Office of Scientific Research and Development and the University of Cincinnati.
}

10,000 feet $(523 \mathrm{~mm} . \mathrm{Hg}), 13,000$ feet $(464 \mathrm{~mm} . \mathrm{Hg}$ ), and 16,000 feet $(412 \mathrm{~mm}$. $\mathrm{Hg}$ ) breathing ambient air; (2) 16,000 feet $(412 \mathrm{~mm}$. $\mathrm{Hg}), 35,000$ feet $(179 \mathrm{~mm} . \mathrm{Hg})$, 39,000 feet $(148 \mathrm{~mm} . \mathrm{Hg}$ ), and 42,500 feet $(125 \mathrm{~mm} . \mathrm{Hg}$ ) breathing commercial oxygen ( 99.3 to 99.7 per cent oxygen) via A-14 demand masks adapted for constant flow ; and (3) Ground, breathing compressed air, and oxygennitrogen mixtures containing 9.75 per cent, 20.95 per cent, 34.6 per cent, 77.9 per cent and 99.5 per cent oxygen, respectively, as determined by analysis in the Haldane apparatus with mixtures containing less than 50 per cent oxygen, and in the Van Slyke-Neill apparatus with mixtures containing more than 50 per cent oxygen.

The first 2 groups of runs were carried out in the decompression chamber, which was constantly and vigorously ventilated in order to prevent accumulation of $\mathrm{CO}_{2}$ or oxygen. On all runs the technic of breathholding was as follows: the subjects, in the sitting position, were instructed to make a maximum exhalation, followed by a maximum inhalation, and then to hold the breath as long as possible. Time was started at the end of inspiration, and ended at the beginning of forced breathing. As far as possible, the subjects were kept in ignorance of the prevailing conditions; during the chamber runs the altimeter was covered so that, although aware of changes in altitude in an upward or downward direction, they did not know the exact altitude. In the ground level runs, the tanks containing the gas mixtures were so situated that their labels could not be read by the subject. At least 5 minutes of preliminary breathing was carried out for each exposure. The replicate determinations were never consecutive, and the order of testing was randomized. Duplicate determinations were carried out for each condition tested. There was some tendency on the part of the individual subjects to improve their breathholding ability during the course of the runs. The effect of this was partially offset by giving the subjects several preliminary trials on the ground in order to bring them to their maximum performance, and further controlled by the randomization of the order of testing. With these controlling factors, namely, randomization of testing, it can be assumed that the amount of gas held in the lungs by the individual subject was relatively constant on each test, and that the average value for a number of subjects gave a measure of the maximum breathholding time for a given amount of gas of given composition in the lungs. 


\section{RESULTS}

The results are shown in Tables I to III. As expected, there was considerable individual variation in breathholding time; i.e., from 61 to 167 seconds with air at ground level, from 128 to 266 seconds with 100 per cent oxygen at ground level, and from 27 to 83 seconds with air at 16,000 feet. However, each individual yielded surprisingly consistent results, once having achieved proficiency in the procedure.

The duration of breathholding varied directly with the $\mathrm{pO}_{2}$ of inspired air (corrected for saturation with water vapor at $37^{\circ} \mathrm{C}$.) although there were occasional individual inconsistencies; i.e., where a subject did better at 10,000 feet than at 7000 feet. Such instances were remarkably few in number. When the average breathholding times, expressed in percentage of values obtained after breathing ground air, are plotted against the percentage of change in the $\mathrm{pO}_{2}$ of the saturated inspired air from ground value, the result is a straight line with a nearly $1: 1$ relationship when the atmospheric $\mathrm{pO}_{2}$ is normal (i.e., ground) or less than normal, using air up to 16,000 feet and, using 100 per cent oxygen at altitudes of $35,000(179 \mathrm{~mm}$.
TABLE I

Breathholding time at different altitudes breathing ambient air

\begin{tabular}{c|c|c|c|c|c}
\hline \hline Altitude in feet & Ground & 7,000 & 10,000 & 13,000 & 16,000 \\
Altitude in mm.Hg & 746 & $\mathbf{5 8 6}$ & $\mathbf{5 2 3}$ & $\mathbf{4 6 4}$ & $\mathbf{4 1 2}$ \\
pO2 of inspired air & 157 & 123 & 110 & 97 & 87 \\
\hline
\end{tabular}

\begin{tabular}{|c|c|c|c|c|c|}
\hline \multicolumn{6}{|c|}{ Average to nearest second of 2 trials at each altitude } \\
\hline $\begin{array}{l}\text { FE } \\
\text { E } \\
\text { FR } \\
\text { GE } \\
\text { CL } \\
\text { SCHU } \\
\text { RU } \\
\text { SL } \\
\text { Mc } \\
\text { BEC } \\
\text { SC } \\
\text { SP } \\
\text { HU } \\
\text { RO } \\
\text { SCH }\end{array}$ & $\begin{array}{r}120 \\
93 \\
97 \\
80 \\
87 \\
74 \\
125 \\
80 \\
67 \\
82 \\
72 \\
108 \\
91 \\
85 \\
100\end{array}$ & $\begin{array}{r}103 \\
73 \\
78 \\
67 \\
58 \\
61 \\
92 \\
61 \\
53 \\
71 \\
62 \\
87 \\
68\end{array}$ & $\begin{array}{r}93 \\
64 \\
72 \\
53 \\
61 \\
58 \\
105 \\
65 \\
48 \\
66 \\
56 \\
93 \\
60 \\
59 \\
75\end{array}$ & $\begin{array}{l}78 \\
62 \\
63 \\
41 \\
42 \\
43 \\
78 \\
50 \\
52 \\
59 \\
51 \\
75 \\
60\end{array}$ & $\begin{array}{l}62 \\
57 \\
57 \\
39 \\
41 \\
47 \\
70 \\
41 \\
39 \\
52 \\
39 \\
49 \\
54 \\
43 \\
58\end{array}$ \\
\hline $\begin{array}{l}\text { Breathholding time: } \\
\text { average in seconds } \\
\text { Breathholding time; } \\
\text { percentage of ground } \\
\mathrm{pO}_{2} \text { of inspired air; } \\
\text { percentage of ground } \\
\text { Calculated } \mathrm{pO}_{2} \text { of in- } \\
\text { spired air after satu- } \\
\text { ration with water } \\
\text { vapor at } 37^{\circ} \mathrm{C} \text {; per- } \\
\text { centage of ground }\end{array}$ & $\begin{array}{c}100 \\
100\end{array}$ & 79 & 73 & $\begin{array}{l}63 \\
63\end{array}$ & $\begin{array}{l}50 \\
55 \\
55\end{array}$ \\
\hline
\end{tabular}

TABLE II

Breathholding time at different altitudes*

\begin{tabular}{|c|c|c|c|c|c|c|c|}
\hline $\begin{array}{l}\text { Altitude in thousands of feet } \\
\text { Altitude mm. Hg } \\
\mathrm{pO}_{2} \text { of inspired air }\end{array}$ & $\begin{array}{l}\text { Ground } \\
746 \\
157\end{array}$ & $\begin{array}{r}35 \\
179 \\
179\end{array}$ & $\begin{array}{r}10 \\
523 \\
110\end{array}$ & $\begin{array}{r}39 \\
148 \\
148\end{array}$ & $\begin{array}{r}16 \\
412 \\
87\end{array}$ & $\begin{array}{r}42.5 \\
125 \\
125\end{array}$ & $\begin{array}{l}16 \mathrm{O}_{2} \\
412 \\
412\end{array}$ \\
\hline $\begin{array}{l}\text { SC } \\
\text { RE } \\
\text { BE } \\
\text { D } \\
\text { P } \\
\text { G } \\
\text { MO } \\
\text { HU } \\
\text { BR } \\
\text { RY } \\
\text { SCHU } \\
\text { MOR } \\
\text { SCHI } \\
\text { SW } \\
\text { BL } \\
\text { FL } \\
\text { FI } \\
\text { BEC }\end{array}$ & $\begin{array}{r}94 \\
76 \\
66 \\
88 \\
116 \\
96 \\
97 \\
120 \\
105 \\
61 \\
63 \\
90 \\
80 \\
160 \\
167 \\
137 \\
108 \\
106\end{array}$ & $\begin{array}{r}A \nu \\
61 \\
70 \\
53 \\
78 \\
84 \\
77 \\
118 \\
98 \\
90 \\
53 \\
65 \\
73 \\
84 \\
118 \\
123 \\
90 \\
67 \\
115\end{array}$ & $\begin{array}{r}\text { to neares } \\
75 \\
61 \\
46 \\
72 \\
74 \\
91 \\
75 \\
91 \\
\\
36 \\
56 \\
60 \\
58 \\
108 \\
110 \\
90 \\
72 \\
84\end{array}$ & $\begin{array}{r}\text { nd of } \\
46 \\
61 \\
42 \\
67 \\
61 \\
61 \\
83 \\
70 \\
80 \\
47 \\
60 \\
55 \\
73 \\
103 \\
103 \\
75 \\
68 \\
90\end{array}$ & $\begin{array}{c}a t \text { eac } \\
51 \\
48 \\
38 \\
53 \\
48 \\
65 \\
60 \\
60 \\
55 \\
27 \\
46 \\
50 \\
50 \\
83 \\
90 \\
80 \\
48 \\
63\end{array}$ & $\begin{array}{l}\text { cde } \\
33 \\
43 \\
39 \\
47 \\
48 \\
52 \\
43 \\
50 \\
65 \\
32 \\
50 \\
39 \\
44 \\
93 \\
60 \\
62 \\
59 \\
60\end{array}$ & $\begin{array}{r}94 \\
90 \\
90 \\
136 \\
137 \\
162 \\
125 \\
160 \\
145 \\
84 \\
113 \\
121 \\
72 \\
210 \\
210 \\
135 \\
125 \\
171\end{array}$ \\
\hline $\begin{array}{l}\text { Breathholding time; average in seconds } \\
\text { Breathholding time; percentage of ground } \\
\text { Calculated pO of inspired air after saturation } \\
\text { with water vapor at } 37^{\circ} \mathrm{C} \text {; percentage of } \\
\text { ground }\end{array}$ & $\begin{array}{l}103 \\
100 \\
100\end{array}$ & $\begin{array}{l}88 \\
85\end{array}$ & $\begin{array}{l}76 \\
74\end{array}$ & $\begin{array}{l}71 \\
69\end{array}$ & $\begin{array}{l}58 \\
56\end{array}$ & $\begin{array}{l}54 \\
52 \\
53\end{array}$ & $\begin{array}{l}136 \\
132 \\
248\end{array}$ \\
\hline
\end{tabular}

* At ground, 10,000 feet and 16,000 feet, subjects breathed ambient air. At the higher altitudes, and at 16,000 feet, as indicated in the last column, they breathed 100 per cent oxygen. 
TABLE III

Breathholding time breathing different oxygen-nitrogen mixtures by mask

\begin{tabular}{|c|c|c|c|c|c|c|c|c|}
\hline $\begin{array}{l}\text { Percentage oxygen content inspired air } \\
\text { pO2 of inspired air }\end{array}$ & $\begin{array}{l}100 \\
746\end{array}$ & $\begin{array}{r}78 \\
582\end{array}$ & $\begin{array}{r}49 \\
366\end{array}$ & $\begin{array}{r}35 \\
261\end{array}$ & $\begin{array}{r}25 \\
187\end{array}$ & $21 *$ & $21+$ & $\begin{array}{l}10 \\
75\end{array}$ \\
\hline $\begin{array}{l}\text { ST } \\
\text { WE } \\
\text { SC } \\
\text { L } \\
\text { HU } \\
\text { FI } \\
\text { FL } \\
\text { D } \\
\text { BL } \\
\text { RE } \\
\text { BE } \\
\text { SCHN } \\
\text { WO } \\
\text { WI } \\
\text { Z } \\
\text { SE } \\
\text { G } \\
\text { STO } \\
\text { STU } \\
\text { C } \\
\text { K } \\
\text { MO } \\
\text { DR }\end{array}$ & $\begin{array}{l}230 \\
142 \\
128 \\
226 \\
191 \\
187 \\
210 \\
266 \\
186 \\
167 \\
181 \\
186 \\
171 \\
161 \\
151 \\
172 \\
148 \\
166 \\
183 \\
162 \\
281 \\
144 \\
182\end{array}$ & $\begin{array}{l}209 \\
137 \\
125 \\
205 \\
153 \\
163 \\
159 \\
240 \\
196 \\
118 \\
125 \\
165 \\
136 \\
143 \\
138 \\
171 \\
137 \\
154 \\
171 \\
148 \\
233 \\
146 \\
176\end{array}$ & $\begin{array}{c}\text { A veras } \\
200 \\
122 \\
114 \\
192 \\
158 \\
142 \\
154 \\
239 \\
160 \\
122 \\
153 \\
157 \\
134 \\
124 \\
132 \\
166 \\
132 \\
137 \\
198 \\
140 \\
219 \\
141 \\
142\end{array}$ & $\begin{array}{c}\text { arest } s \\
167 \\
114 \\
112 \\
169 \\
138 \\
134 \\
123 \\
228 \\
152 \\
112 \\
128 \\
132 \\
108 \\
117 \\
103 \\
162 \\
129 \\
131\end{array}$ & $\begin{array}{r}114 \\
110 \\
72 \\
157 \\
116 \\
112 \\
130 \\
119 \\
150 \\
124 \\
113\end{array}$ & $\begin{array}{r}\text { each } \\
116 \\
70 \\
96 \\
132 \\
92 \\
102 \\
117 \\
154 \\
79 \\
105 \\
81 \\
97 \\
97 \\
99 \\
69 \\
148 \\
91 \\
81 \\
100 \\
113 \\
129 \\
100 \\
91\end{array}$ & $\begin{array}{r}129 \\
83 \\
97 \\
129 \\
102 \\
96 \\
108 \\
120 \\
102 \\
105 \\
56 \\
80 \\
107 \\
108 \\
93 \\
140 \\
107 \\
77 \\
94 \\
100 \\
125 \\
119 \\
100\end{array}$ & $\begin{array}{l}76 \\
43 \\
50 \\
75 \\
65 \\
49 \\
58 \\
92 \\
34 \\
45 \\
44 \\
47 \\
41 \\
44 \\
34 \\
58 \\
33 \\
40 \\
52 \\
21 \\
51 \\
55 \\
41\end{array}$ \\
\hline $\begin{array}{l}\text { Breathholding time; average in } \\
\text { seconds } \\
\text { Breathholding time; percentage of } \\
\text { ground } \\
\mathrm{pO}_{2} \text { of inspired air; percentage of } \\
\text { ground } \\
\mathrm{Calculated} \mathrm{pO}_{2} \text { of inspired air after } \\
\text { saturation with water vapor at } \\
37^{\circ} \mathrm{C} \text {; percentage of ground }\end{array}$ & $\begin{array}{l}179 \\
174 \\
476 \\
476\end{array}$ & $\begin{array}{l}163 \\
158 \\
373 \\
372\end{array}$ & $\begin{array}{r}155 \\
150 \\
234\end{array}$ & $\begin{array}{l}140 \\
136 \\
167\end{array}$ & $\begin{array}{l}120 \\
117 \\
119\end{array}$ & $\begin{array}{l}103 \\
100 \\
100\end{array}$ & $\begin{array}{l}103 \\
100 \\
100\end{array}$ & $\begin{array}{l}50 \\
49 \\
48\end{array}$ \\
\hline
\end{tabular}

* From compressed air tank.

† Room air, no mask used.

$\mathrm{Hg}), 39,000$ feet $(148 \mathrm{~mm} . \mathrm{Hg})$ and 42,500 feet $\left(125 \mathrm{~mm} . \mathrm{Hg}\right.$ ) (Figure 1). However, with $\mathrm{pO}_{2}$ higher than normal, increasing the $\mathrm{pO}_{2}$ of inspired air has progressively less effect in increasing the breathholding time; for example, with 100 per cent oxygen (atmospheric $\mathrm{pO}_{2} 475$ per cent of ground) the breathholding time is increased only to 174 per cent of the ground value. This is illustrated by the loss of the straight line relationship between average breathholding times (expressed as percentage of values of ground air) and percentage of change in $\mathrm{pO}_{2}$ of saturated inspired air, when the latter is above normal (Figure 2).

\section{DISCUSSION}

The data indicate that the effect of the $\mathrm{pO}_{2}$ of inspired air on the maximum time of breathholding is most striking. Although there are some discrepancies in this relation in certain individuals, it is quite evident that, in this small group, a signifi- cant decrease in breathholding time as compared to that on the ground can be detected at altitudes as low as 7000 feet. In view of the simplicity of this test, and the short time required to indoctrinate subjects for it and to carry it out, it appears to have value as a method for demonstrating physiological alterations to relatively small changes in the $\mathrm{pO}_{2}$ of inspired air. Its usefulness in the indoctrination of aviation candidates has already been pointed out (2).

Of more interest is the relation of the change in breathholding time to change in $\mathrm{pO}_{2}$ at levels less than ground. Here, for every increment of $\mathrm{pO}_{2}$ change, there is an equal change of increment in the breathholding time. In the case of inspired $\mathrm{pO}_{2}$ greater than ground values, the effect of the increased tension in lengthening the breathholding time becomes less and less as the $\mathrm{pO}_{2}$ increases.

This would indicate that at $\mathrm{pO}_{2}$ of ground level or less, the $\mathrm{pO}_{2}$ of the inspired air appears to be of 

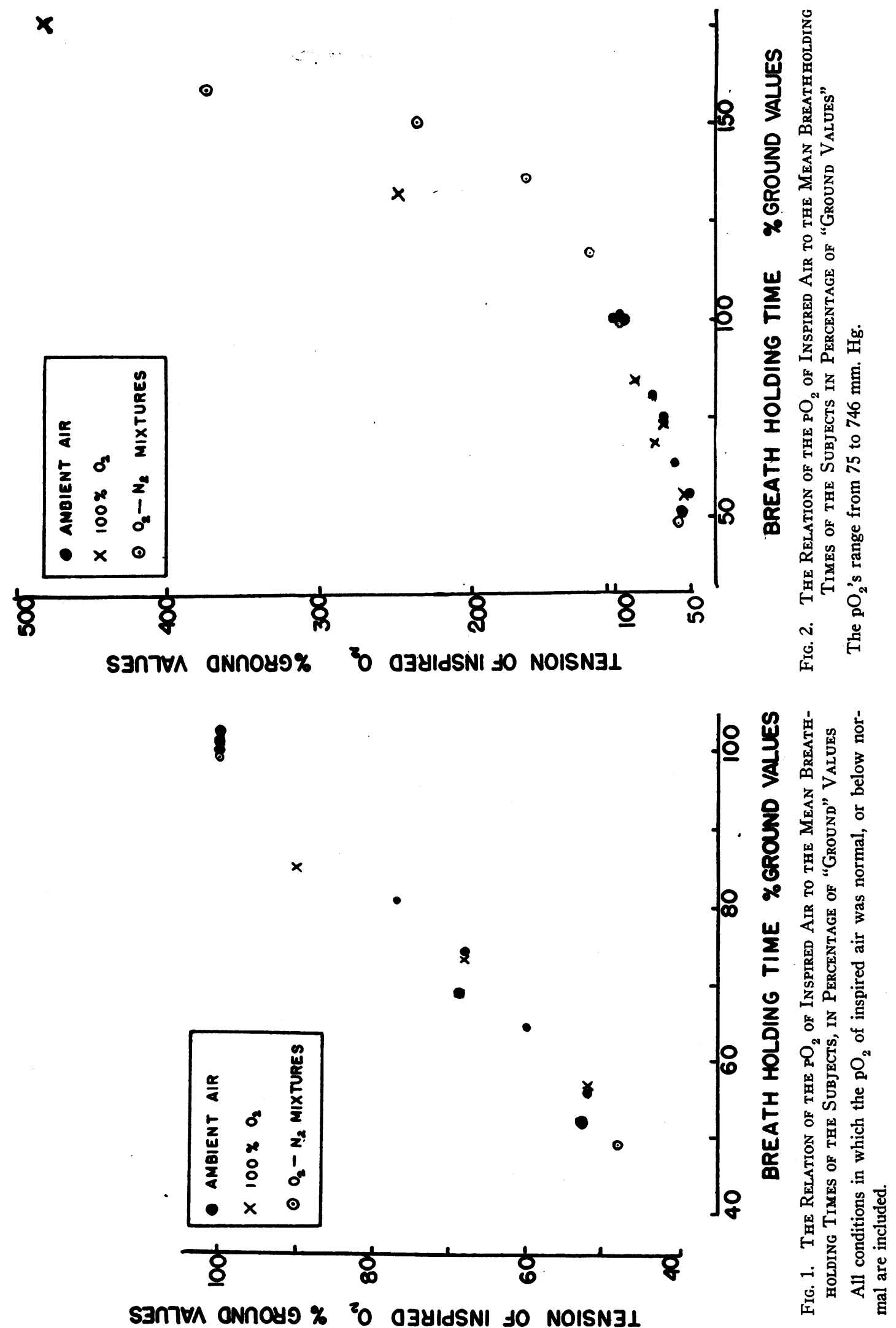

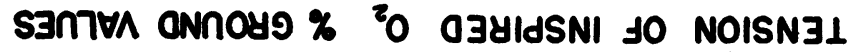


major importance in determining when the subject shall breathe after maximum breathholding. At $\mathrm{pO}_{2}$ greater than that on the ground $(160 \mathrm{~mm}$. $\mathrm{Hg}$ ), oxygen, although still influencing the stimulus to breathe, becomes less effective as its tension rises, while another factor (presumably $\mathrm{pCO}_{2}$ of the blood) becomes more effective as a respiratory stimulant.

It is evident, then, that oxygen lack takes on considerable importance as a respiratory stimulant under certain conditions, and that the relative roles of oxygen and $\mathrm{CO}_{2}$ in influencing respiration are variable with respect to the oxygen tension of the inspired air.

\section{SUMMARY}

From ground levels to altitudes up to 16,000 feet the maximum breathholding time varies in direct propotion to the change in atmospheric pressure $\left(\mathrm{pO}_{2}\right.$ of inspired air). Identical changes are noted on the ground when equivalent gas mixtures are inspired by mask. Breathing of oxy- gen mixtures from 21 to 100 per cent progressively increases the breathholding time, but the effect becomes less and less as the $\mathrm{pO}_{2}$ approaches 760 $\mathrm{mm} . \mathrm{Hg}$.

The breathholding technic offers a simple method for objective demonstration of physiologic changes at relatively low altitudes. A decrease in breathholding time occurred at 7000 feet in all individuals tested.

We are indebted to Jane K. Friedlander for her technical assistance.

\section{BIBLIOGRAPHY}

1. Hill, L., and Flack, M., The effect of excess carbon dioxide and of oxygen upon the respiration and circulation. J. Physiol., 1908, 37, 77.

2. Flack, M., Some simple tests of physical efficiency. Lancet, 1919, 1, 210.

3. Schneider, E. C., Observations on holding the breath. Am. J. Physiol., 1930, 94, 464.

4. Engel, G. L., Webb, J. P., and Ferris, E. B., Unpublished observations, 1943. 